\title{
Antioxidant activity and phenol content of extracts of bark, stems, and young and mature leaves from Blepharocalyx salicifolius (Kunth) O. Berg
}

\author{
E. Habermann ${ }^{a *}$, M. Imatomi ${ }^{b}$, F. C. Pontes ${ }^{b}$ and S. C. J. Gualtieri ${ }^{b}$ \\ ${ }^{a}$ Grupo de Pesquisa em Ecofisiologia de Plantas Tropicais, Laboratório de Fisiologia Vegetal, \\ Departamento de Biologia, Faculdade de Filosofia, Ciências e Letras de Ribeirão Preto, \\ Universidade de São Paulo - USP, Av. Bandeirantes, 3900, Monte Alegre, CEP 14040-901, Ribeirão Preto, SP, Brazil \\ ${ }^{\mathrm{b}}$ Grupo de Pesquisa em Fitoquímica e Ecofisiologia de Reprodução Vegetal, Laboratório de Sementes, \\ Departamento de Botânica, Centro de Ciências Biológicas e da Saúde, Universidade Federal de São Carlos - UFSCar, \\ Washington Luís, Km 235, CP 676, CEP 13565-905, São Carlos, SP, Brazil \\ *e-mail: eduardohabermann@gmail.com
}

Received: March 6, 2015 - Accepted: October 6, 2015 - Distributed: November 30, 2016

(With 2 figures)

\begin{abstract}
Phenolic compounds are a group of plant secondary metabolites known to have a variety of bioactivities, including the ability to function as antioxidants. Because of the side effects of the use of synthetic substances, the search for natural and less toxic compounds has increased significantly. This study was designed to evaluate the antioxidant activity and phenol content of hexane, ethyl acetate, and aqueous extracts of the bark (suber) and stems as well as the young and mature leaves of Blepharocalyx salicifolius. The extracts were obtained by extraction with organic solvents and subsequent fractionation by chromatographic partition coefficient. Preliminary tests for the presence of antioxidants were performed using bioautography in thin-layer chromatography. The antioxidant activity of the extracts was assessed using the 2,2-diphenyl-1-picrylhydrazyl (DPPH) method, and the phenol content of the extracts was quantified using the Folin-Ciocalteu technique. The results showed that 9 of the 12 extracts evaluated displayed very strong antioxidant activity and three displayed moderate activity. Aqueous extracts of the young leaves and bark and the ethyl acetate extract of the young leaves showed the highest levels of antioxidant activity and total phenolic content (TPC). A correlation was observed between TPC and antioxidant activity index (AAI) with a correlation coefficient $\left(\mathrm{r}^{2}\right)$ of 0.7999 . Thus, the high phenol content of $B$. salicifolius extracts and its correlation with antioxidant activity provide substrates for further studies.
\end{abstract}

Keywords: bioactivity, Brazilian Savana (Cerrado), leaf maturation stage, Myrtaceae, scavenging free radicals.

\section{Atividade antioxidante e teor de polifenóis de extratos de cascas (súber), caule, folhas jovens e folhas maduras de Blepharocalyx salicifolius (Kunth) O. Berg (Murta)}

\begin{abstract}
Resumo
Os polifenóis são um grupo de metabólitos secundários vegetais que possuem uma variedade de bioatividades conhecidas, dentre elas a capacidade de funcionar como antioxidantes. Devido aos efeitos colaterais do uso excessivo de substâncias sintéticas, a busca por compostos naturais e menos tóxicos têm aumentado significativamente. Esse estudo teve por objetivo avaliar a atividade antioxidante e o teor de polifenóis dos extratos hexânicos, acetato de etila e aquosos de cascas (súber), caules, folhas jovens e folhas maduras de Blepharocalyx salicifolius. Os extratos foram obtidos por meio de extração com solventes orgânicos e subsequente fracionamento em cromatografia por coeficiente de partição. Testes preliminares da presença de compostos com atividade antioxidante foram realizados por meio de bioautografia em cromatografia de camada delgada. Os extratos foram submetidos ao teste da capacidade sequestrante do radical 2,2-difenil-1-picrilhidrazil (DPPH) para quantificação da atividade antioxidante e submetidos ao teste com o reagente de Folin-Ciocalteu para quantificação dos polifenóis. Os resultados mostraram que dos 12 extratos avaliados, 9 apresentaram atividade antioxidante muito forte e 3 atividade moderada. Os extratos aquosos de folhas jovens e cascas e o extrato acetato de etila de folhas jovens apresentaram os maiores índices de atividade antioxidante e teor de polifenóis (TPC). A correlação entre TPC e o índice de atividade antioxidante (AAI) observada foi de $r^{2}=0,7999$. Dessa forma, ficou evidenciado o elevado teor de polifenóis e sua correlação com a atividade antioxidante nos extratos de B. salicifolius, fornecendo subsídios para novos estudos.
\end{abstract}

Palavras-chave: bioatividade, Cerrado, estágio de maturação foliar, Murta, sequestro de radicais livres. 


\section{Introduction}

Production of reactive oxygen species (ROS) occurs naturally in living organisms as a result of oxidative metabolism (Rahman and Adcock, 2006). In situations of imbalance, these compounds are produced in excess and their interaction with biomolecules leads to pathological states (Arts and Hollman, 2005). Recent research has shown that oxidative stress promoted by free radicals is linked to the etiology of diseases such as Parkinson's disease, cancer, myocardial infarction, and atherosclerosis (Vellosa et al., 2007; Zarena and Sankar, 2009). In addition, oxidative stress is harmful to the food industry, changing the smell, taste, and nutritional value of food (Krings and Berger, 2001).

Compounds capable of preventing or delaying the oxidation of biomolecules by free radicals are called antioxidants (Halliwell et al., 1995). Because of the side effects from the use of synthetic compounds (Yildirim et al., 2001), the search for natural substances that can be used as antioxidants in the food, cosmetic and health industries has been intensified (Repetto and Llesuy, 2002). In plants, these compounds are mainly represented by polyphenols, such as flavonoids, and carotenoids (Lizcano et al., 2010).

Polyphenols are a heterogeneous group of secondary metabolites that have a basic structure containing a functional hydroxyl group attached to an aromatic ring. Many of these compounds are carotenoids such as xanthophylls, and flavonoids. Carotenoids are found in leaves and fruits, where they act as accessory pigments in the photosynthetic process and confer vivid colors to the fruits. Flavonoids such as anthocyanins, flavonols, and flavones accumulate in the epidermis and protect the plant body from the harmful effects of exposure to ultraviolet light (Manach et al., 2005; Taiz and Zeiger, 2013). Therefore, most researchers have focused their efforts on evaluating the antioxidant activity and polyphenol content of leaves or fruit extracts. Studies evaluating the antioxidant activity and polyphenol content in stem bark (suber) or stem extracts are poorly reported in the literature.

Few studies evaluate the antioxidant activity of Myrtaceae species from the Brazilian Savanna (Cerrado). In this phytophysiognomy, plants are exposed to a series of extreme environmental conditions. The loss of leaves are costly physiological processes from an energy point of view (Fine et al., 2006). Thus, plants produce higher concentrations of secondary metabolites such as polyphenols to protect themselves from attack by herbivores and from intense solar radiation (Hartmann, 1996).

Popularly known as murta, Blepharocalyx salicifolius (Kunth) O. Berg, found in the Brazilian Savanna (Cerrado), belongs to the Myrtaceae family (Denardi and Marchiori, 2005; Rego et al., 2010). The fruit has strong antioxidant activity and high concentrations of anthocyanins, vitamin C, flavonoids, and carotenoids (Rufino, 2008). Previous studies have shown antioxidant activity in leaf extracts from this species (Ceron et al., 2007) as well the presence of saponins, phenolic compounds, anthraquinones, flavonoids, and tannins in their leaves (Suyenaga et al., 2007; Romero et al., 2012). However, studies evaluating the antioxidant potential of the bark (suber), stems, or leaf extracts from $B$. salicifolius at different stages of maturation have not been reported in the literature.

Thus, this study was designed to evaluate the antioxidant activities of hexane, ethyl acetate, and aqueous extracts of the bark (suber), stems, young leaves, and mature leaves of $B$. salicifolius as well as the concentration of polyphenols in these tissues.

\section{Material and Methods}

\subsection{Plant materials}

Stem bark (suber), stems, young leaves, and mature leaves from B. salicifolius (Kunth) O. Berg were collected at the Brazilian Savanna (Cerrado) of the Federal University of São Carlos (21 '58'5'S and 4753'12'W) in September 2012 (average temperature: $20.7^{\circ} \mathrm{C}$; mean relative humidity of

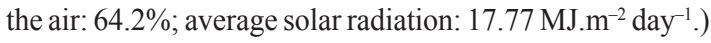
(EMBRAPA, 2015). According to Köeppen (1948), this region has a rainy summer (October to March) and a dry winter (April to September). In this way, it is possible to categorize the climate as Aw. The leaves were classified as young or mature according to the absence or presence of membranous texture (Habermann et al., 2015a), respectively. Stem barks (suber) and stems were collected from young branches, without epiphytic organisms. All plant material was washed in water, dried in a forced-air oven for $72 \mathrm{~h}$ at $40{ }^{\circ} \mathrm{C}$, and then ground separately on an electric mill to obtain a powder of each tissue studied.

\subsection{Obtaining extracts}

The powder obtained from each plant material was subjected to extraction with $\mathrm{CH}_{2} \mathrm{Cl}_{2} / \mathrm{CH}_{3} \mathrm{OH}(1: 1 \mathrm{v} / \mathrm{v})$ in an ultrasound bath for $30 \mathrm{~min}$ (Rostagno et al., 2003). The mixture was filtered through a Büchner funnel containing filter paper (pore size, $0.22 \mu \mathrm{m}$ ) connected to a vacuum pump. This process was repeated five times for each biological material. After drying, the extracts were solubilized in a mixture of $\mathrm{CH}_{3} \mathrm{OH} / \mathrm{H}_{2} \mathrm{O}(95: 5 \mathrm{v} / \mathrm{v})$ and partitioned with hexane to give rise to the hexane and methanolic extracts. The dry methanol extracts were solubilized in distilled water and partitioned with ethyl acetate to give rise to the ethyl acetate and aqueous extracts (Otsuka, 2005). The extracts were dried on a rotary evaporator and stored under refrigeration at $5{ }^{\circ} \mathrm{C}$ until they were used in the experiments described below.

\subsection{Chemicals}

Sodium carbonate, acetone, and methanol were obtained from Synth. Quercetin and 2,2-diphenyl-1-picrylhydrazyl (DPPH) were obtained from Sigma Aldrich. Gallic acid was obtained from Vetec, Folin-Ciocalteu reagent from Haloquímica, and thin-layer chromatography (TLC) plates (normal or reverse phase) from Merck. 


\subsection{Bioautography in thin layer chromatography}

The presence of compounds with antioxidant activity in the crude extracts was determined, on a qualitative basis using the method of Chaaib (Chaaib et al., 2003) with modifications by Luo et al. (2009). The extracts were solubilized in acetone $\left(1 \mathrm{mg} \cdot \mathrm{ml}^{-1}\right)$, deposited directly into a normal phase silica chromatography plates for hexane and ethyl acetate extracts or a reverse-phase chromatography plate for aqueous extracts, and then eluted with different solvents according to the polarity of the compounds evaluated. After elution, the plates were sprayed with a solution of DPPH (0.4 mg. ml $\left.{ }^{-1}\right)$; compounds with antioxidant activity were visualized as white bands on a purple background.

\subsection{Antioxidant activity assay}

Extracts containing antioxidants in the qualitative test were further assessed using the DPPH method described by Scherer and Godoy (2009), with modifications. Aliquots $(0.05 \mathrm{ml})$ of the extracts solubilized in methanol at different concentrations were added to tubes containing $1.95 \mathrm{ml}$ of a $0.08 \mathrm{mM}$ methanolic solution of DPPH. The final concentration of DPPH in each tube after the addition of controls or extracts was $30.75 \mu \mathrm{l} . \mathrm{ml}^{-1}$. Two controls reactions were performed. The negative control contained pure methanol whereas the positive control contained the flavonoid quercetin. After incubation for $90 \mathrm{~min}$ in the dark at room temperature, the absorbance was measured at $517 \mathrm{~nm}$. Each experiment was performed in triplicate and all solutions and controls were prepared daily.

The antioxidant activity was calculated according to the equation: $\mathrm{I} \%=\left[\left(\mathrm{Abs}_{0}-\mathrm{Abs}_{1}\right) / \mathrm{Abs}_{0}\right] \times 100, \mathrm{I} \%$ is the percent inhibition, $\mathrm{Abs}_{0}$ is the absorbance of the negative control, and $\mathrm{Abs}_{1}$ is the absorbance of the tested extract. The extracts were tested at several different concentrations. The $\mathrm{IC}_{50}$ (concentration at which there is $50 \%$ inhibition) was calculated graphically by linear regression of a plot of the antioxidant activities at several extracts concentrations. The antioxidant activity of each extract is expressed using the antioxidant activity index $(\mathrm{AAI})$ as follows: $\mathrm{AAI}=$ final concentration of DPPH $\left(\mu \mathrm{l} \cdot \mathrm{ml}^{-1}\right) / \mathrm{IC}_{50}\left(\mu \mathrm{g} \cdot \mathrm{ml}^{-1}\right)$.

Then, the extracts were classified using the antioxidant activity index established by Scherer and Godoy (2009). In this index, the extracts are classified as: weak $(\mathrm{AAI}<0.5)$, moderate (AAI 0.5-1.0), strong (AAI 1.0-2.0), and very strong $(>2.0)$.

\subsection{Total phenolics determination assay}

The total phenolics content (TPC) was determined using the Folin-Ciocalteu technique (Singleton and Rossi, 1965), as adapted and optimized by George et al. (2005). Aliquots $(2.5 \mathrm{ml})$ of Folin-Ciocalteu reagent solubilized in distilled water $(1 / 10)$ were added to the previously solubilized extracts in methanol. The mixtures were incubated for $2 \mathrm{~min}$ at room temperature, and then $2 \mathrm{ml}$ of sodium carbonate ( 75 g. $\left.1^{-1}\right)$ were added to each of them. The reactions were incubated for $15 \mathrm{~min}$ at $50{ }^{\circ} \mathrm{C}$ in a water bath before being cooled in an ice-water bath. At this point, the absorbance was measured at $760 \mathrm{~nm}$. A calibration curve was prepared with gallic acid (1-8 $\mu \mathrm{g} \cdot \mathrm{ml}^{-1}$ ) (see Figure 1). The TPC of the extracts was represented as milligrams of gallic acid equivalents per gram of dry extract (mg GAE/ g extract), according to the calibration curve where $\mathrm{y}=0.1351$, $x=-0.0115\left(r^{2}=0.9927\right)$, where $y$ denotes the absorbance at $760 \mathrm{~nm}$ and $\mathrm{x}$ denotes the concentration of gallic acid in mg. $1^{-1}$ (Figure 1). Correlations between TPC and AAI values were calculated.

\section{Results}

The efficiency of the chemical extraction method used in this study varied between 0.46 and $10.69 \%$; the extracts from young leaves showed the highest yields (see Table 1).

Bioautography on thin layer chromatography (TLC) plates showed that all extracts contained antioxidants. As a result, each of these extracts was examined for antioxidant activity by using the DPPH method and the TPC was determined for each of them.

Nine extracts displayed a very strong AAI and three showed a moderate AAI, according to the criteria established by Scherer and Godoy (2009) (see Table 1). The most significant values were found in the aqueous extracts of young leaves and bark and in the ethyl acetate extract of young leaves.

The TPCs ranged from 37.32 to $440.40 \mathrm{mg} \mathrm{GAE} / \mathrm{g}$ of extract. The most pronounced values of TPC were found in the aqueous extracts of young leaves $(440.40 \mathrm{mg}$ GAE/g of extract) and bark (suber) (391.84 mg GAE/g of extract) and in the ethyl acetate extract of young leaves (389.24 mg GAE/g of extract). There was a high correlation $\left(\mathrm{r}^{2}=0.7999\right)$ between the antioxidant activities and the TPCs of the extracts evaluated (see Figure 2).

\section{Discussion}

Phenolic compounds derived from vegetable products are recognized to have antioxidant activities that act as auxiliaries in the functioning of the endogenous immune system (Hakime-Silva et al., 2013) and the antioxidant potential of blood plasma (Vinson et al., 2005). Thus, consumption of high concentrations of these compounds leads to a reduced incidence of chronic and degenerative diseases (Shahidi, 1997).

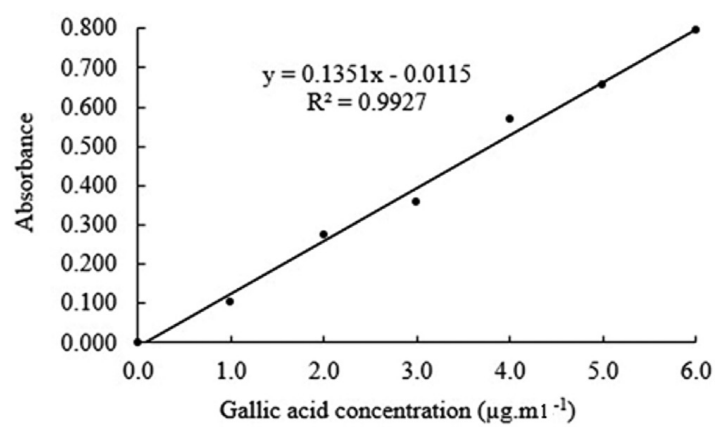

Figure 1. Calibration curve with gallic acid. 
Table 1. Antioxidant Activity Index (AAI) and total phenolic content (TPC) in extracts of bark (suber), stems, young leaves, and mature leaves from Blepharocalyx salicifolius. The pure compound quercetin was used as a control.

\begin{tabular}{|c|c|c|c|c|c|c|c|c|}
\hline \multirow[b]{2}{*}{ Extracts } & \multicolumn{3}{|c|}{$\mathbf{r}^{2}$} & \multirow{2}{*}{$\begin{array}{c}\mathrm{IC}_{\mathbf{5 0}} \\
\left(\mu \mathrm{g} \cdot \mathrm{ml}^{1}\right)\end{array}$} & \multirow[b]{2}{*}{$\mathbf{A A I} \pm \mathbf{D V}$} & \multirow{2}{*}{$\begin{array}{c}\text { Antioxidant } \\
\text { activity }\end{array}$} & \multirow{2}{*}{$\begin{array}{c}\mathrm{TCP} \pm \mathrm{DV} \\
(\mathrm{mg} \mathrm{GAE} / \mathrm{g} \\
\text { dry extract) }\end{array}$} & \multirow{2}{*}{$\begin{array}{l}\text { Extraction } \\
\text { Yield (\%) }\end{array}$} \\
\hline & I & II & III & & & & & \\
\hline Quercetin & 0.9718 & 0.9987 & 0.9949 & 2.02 & $15.25 \pm 0.48$ & Very strong & - & \\
\hline $\begin{array}{l}\text { Young leaves } \\
\text { (Water) }\end{array}$ & 0.9989 & 0.9989 & 0.9958 & 4.16 & $7.40 \pm 0.06$ & Very strong & $440.40 \pm 2.47$ & 10.69 \\
\hline Bark (Water) & 0.9911 & 0.9970 & 0.9988 & 4.73 & $6.50 \pm 0.04$ & Very & $391.84 \pm 4.90$ & 0.49 \\
\hline $\begin{array}{l}\text { Young leaves } \\
\text { (Ethyl acetate) }\end{array}$ & 0.9967 & 0.9997 & 0.9960 & 5.31 & $5.80 \pm 0.04$ & Very strong & $389.24 \pm 19.99$ & 5.88 \\
\hline Stem (Water) & 0.9923 & 0.9941 & 0.9975 & 6.74 & $4.51 \pm 0.10$ & Very & $201.92 \pm 8.52$ & 2.65 \\
\hline $\begin{array}{l}\text { Mature leaves } \\
\text { (Water) }\end{array}$ & 0.8983 & 0.9023 & 0.9577 & 7.74 & $3.98 \pm 0.14$ & Very strong & $276.61 \pm 26.51$ & 9.95 \\
\hline $\begin{array}{l}\text { Mature leaves } \\
\text { (Ethyl acetate) }\end{array}$ & 0.9953 & 0.9733 & 0.9729 & 8.49 & $3.62 \pm 0.08$ & Very strong & $117.95 \pm 19.29$ & 5.79 \\
\hline $\begin{array}{l}\text { Stem } \\
\text { (Ethyl acetate) }\end{array}$ & 0.9874 & 0.9482 & 0.9906 & 11.95 & $2.57 \pm 0.04$ & Very strong & $120.41 \pm 1.86$ & 0.64 \\
\hline $\begin{array}{l}\text { Bark } \\
\text { (Ethyl acetate) }\end{array}$ & 0.9912 & 0.9548 & 0.9947 & 12.46 & $2.47 \pm 0.15$ & Very strong & $300.40 \pm 2.72$ & 0.84 \\
\hline Bark (Hexane) & 0.8732 & 0.8218 & 0.8954 & 12.65 & $2.43 \pm 0.24$ & Very strong & $94.37 \pm 4.56$ & 0.83 \\
\hline Stem (Hexane) & 0.9364 & 0.9766 & 0.9742 & 33.81 & $0.91 \pm 0.02$ & Moderate & $68.3 \pm 1.32$ & 0.46 \\
\hline $\begin{array}{l}\text { Young leaves } \\
\text { (Hexane) }\end{array}$ & 0.9673 & 0.9438 & 0.9670 & 35.02 & $0.88 \pm 0.01$ & Moderate & $84.51 \pm 4.62$ & 4.09 \\
\hline $\begin{array}{l}\text { Mature leaves } \\
\text { (Hexane) }\end{array}$ & 0.8928 & 0.9962 & 0.9899 & 53.40 & $0.58 \pm 0.01$ & Moderate & $37.32 \pm 2.67$ & 2.99 \\
\hline
\end{tabular}

$\mathrm{r}^{2}$ : coefficient of determination between the antioxidant activity and the concentration of the extract/quercetin solution in each repetition (I, II, and $\mathrm{III}) . \mathrm{IC}_{50}$ : concentration displaying 50\% inhibition. DV: standard deviation. Antioxidant activity: power antioxidant activity by Scherer and Godoy (2009). GAE: Gallic acid equivalent.

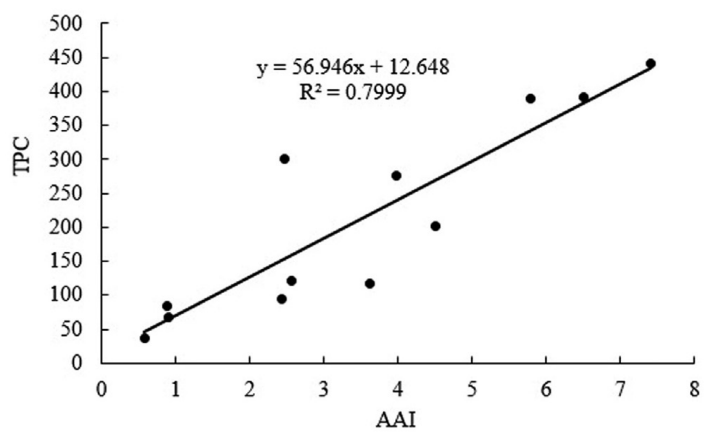

Figure 2. Linear correlation between the total phenolic compounds (TPC: in mg of gallic acid equivalents/g dry extract) and antioxidant activity index (AAI) of extracts of the bark and stems as weel as the young and mature leaves from Blepharocalyx salicifolius.

In a study by Frosi et al. (2012), an aqueous extract of leaves from $B$. salicifolius showed an antioxidant activity of $83.83 \%$ at a concentration of $20 \mu \mathrm{g} \cdot \mathrm{ml}^{-1}$. Infusions of B. salicifolius leaves are used for therapeutic purposes (Ceron et al., 2007) in the treatment of diseases such as sinusitis, cystitis, urethritis, cough, bronchitis, high blood pressure, and rheumatism (Suyenaga et al., 2007; Romero et al., 2012; Piriz et al., 2013; Fuão, 2014). Extracts of plants of this species, are also recognized to have antibacterial, leishmanicidal, anti-inflammatory, and phytotoxic properties (Ceron et al., 2007; Siqueira et al., 2011; Vivot et al., 2012; Habermann et al., 2015b).

The composition of the essential oils from the leaves of B. salicifolius is widely known to have high concentrations of $\alpha$-eudesmol, $\gamma$-eudesmol, elemol, globulol, and $\alpha$-pinene (Godinho et al., 2014). However, few polyphenols were isolated from this species. In the study by Siqueira et al. (2011), flavonoids such as quercitrin were isolated from leaf extracts of $B$. salicifolius, which may be related to antioxidant activity observed in the present study. As seen in Table 1, extracts of bark and stems showed high levels of phenolic compounds and antioxidant activity. These results demonstrate the importance of studies assessing these parameters in all plant structures.

The production of polyphenol depends on both environmental factors (light and water status of the plant) and endogenous factors (maturation stage). Thus, it is essential to specify the conditions under which the plant material was collected (Gobbo-Neto and Lopes, 2007). The relevance of this information can be observed in the different values of AAI and TPC observed for the extracts of young and mature leaves (see Table 1). Christofoletti and Pinheiro (2005) observed that the concentration of polyphenols from young, mature, and senescent leaves remains constant in Avicennia schaueriana (Acanthaceae), decreases with age 
in Laguncularia racemosa (Combretaceae), and increases with age in Rhizophora mangle (Rhizophoraceae). Therefore, it is not possible to establish a general correlation between the content of these compounds and the maturation stage. However, few studies distinguish the leaf maturation stage when evaluating the antioxidant activity and TPC (Barreto et al., 2008; Abdallah et al., 2012).

Different methodologies has been used to determine the antioxidant activity of plant extracts. In this context, the most widely used method is the radical scavenging capacity of DPPH. The result is based on color change (from purple to yellow), and then the absorbance variation. These alterations occurs when the electron of nitrogen in the DPPH molecule is reduced by receiving a hydrogen atom or electron from antioxidants (Ozcelik et al., 2003).

The results obtained by Donatini et al. (2009) using the DPPH method showed that an ethanolic extract of the leaf from Syzygium jambos (Myrtaceae) had an $\mathrm{IC}_{50}$ of $5.68 \mathrm{mg} \cdot \mathrm{ml}^{-1}$, a value below that of the three extracts with a higher AAI observed in the present study. Pure compounds such as rutin and ferulic acid, evaluated by Scherer and Godoy (2009) have AAIs of 5.12 and 6.77, respectively, which are below the values observed in this study for the aqueous extracts of young leaves and bark.

This study was the first report of the antioxidant activity of extracts from the stem and bark of the B. salicifolius. Furthermore, this study evaluated the differences between the activities of young and mature leaves, indicating the importance of the collection period. Such studies are useful in exploiting the natural resources of the Brazilian Savanna (Cerrado), thereby providing new justification for the environmental conservation of this vegetation type. This study shows the high phenol content and antioxidant activity of bark and stems as weel as the young and mature leaves from B. salicifolius. It was observed that the aqueous extracts of young leaves and bark have the highest AAI and TPC values.

\section{Acknowledgements}

This work was supported by the Sao Paulo Research Foundation, FAPESP (process $n^{\circ} 12 / 17714-3$ ), CAPES, and CNPq.

\section{References}

ABDALLAH, S.B., RABHI, M., HARBAOUI, F., ZAR-KALAI, F., LACHÂAL, M. and KARRAY-BOURAOUI, N., 2012. Distribution of phenolic compounds and antioxidant activity between young and old leaves of Carthamus tinctorius L. and their induction by salt stress. Acta Physiologiae Plantarum, vol. 35, no. 4, pp. 1161-1169. http://dx.doi.org/10.1007/s11738-012-1155-z.

ARTS, I.C. and HOLLMAN, P.C., 2005. Polyphenols and disease risk in epidemiological studies. The American Journal of Clinical Nutrition, vol. 81, no. 1, (suppl.), pp. 317-325. PMid:15640497.

BARRETO, J.C., TREVISAN, M.T.S., HULL, W.E., ERBEN, G., BRITO, E.S., PFUNDSTEIN, B., WÜRTELE, G., SPIEGELHALDER, B. and OWEN, R.W., 2008. Characterization and quantification of polyphenolic compounds in bark, kernel, leaves, and peel of Mango (Mangifera indica L.). Journal of Agricultural and Food Chemistry, vol. 56, no. 14, pp. 5599-5610. http://dx.doi. org/10.1021/jf800738r. PMid:18558692.

CERON, C.S., ZANOTTO, C.Z., SILVEIRA, R.S., KUNZ, V.T., WALKER, C.I.B. and MANFRON, M.P., 2007. Atividade antioxidante dos extratos de Blepharocalyx salicifolius (H.B.K.) Berg. In: Proceedings of the I Congresso Sul Americano de Farmácia, 8-11 November 2010, Maringá, Brazil. Maringá: ARQ MUDI, pp. 1-2.

CHAAIB, F., QUEIROZ, E.F., NDJOKO, K., DIALLO, D. and HOSTETTMANN, K., 2003. Antifungal and antioxidant compounds from the root bark of Fagara zanthoxyloides. Planta Medica, vol. 69, no. 4, pp. 316-320. http://dx.doi.org/10.1055/s-2003-38877. PMid:12709897.

CHRISTOFOLETTI, R.A. and PINHEIRO, A.A., 2005. Variações intra e interespecíficas de polifenóis nas principais espécies arbóreas de mangue na região de Iguape (SP). In: Proceedings of the VII Congresso de Ecologia do Brasil, 20-25 November 2005, Caxambu, Brazil. São Paulo: Ecological Society of Brazil, pp. 1-2.

DENARDI, L. and MARCHIORI, J.N.C., 2005. Anatomia ecológica da madeira de Blepharocalyx salicifolius (H.B.K) Berg. Ciência Florestal, vol. 15, no. 2, pp. 119-127.

DONATINI, R.S., ISHIKAWA, T., BARROS, S.B.M. and BACCHI, E.M., 2009. Atividades antiúlcera e antioxidante do extrato de folhas de Syzygium jambos (L.) Alston (Myrtaceae). Revista Brasileira de Farmacognosia, vol. 19, no. 1, pp. 89-94. http://dx.doi.org/10.1590/S0102-695X2009000100018.

EMPRESA BRASILEIRA DE PESQUISAAGROPECUÁRIAEMBRAPA, 2015 [viewed 14 February 2015]. Dados meteorológicos [online]. São Carlos: EMBRAPA. Available from: http://www. cppse.embrapa.br/dados-meteorologicos

FINE, P.V.A., MILLER, Z.J., MESONES, I., IRAZUZTA, S., APPEL, H.M., STEVENS, M.H.H., SÄÄKSJÄRVI, I., SCHULTZ, J.C. and COLEY, P.D., 2006. The growth-defense trade-off and habitat specialization by plants in Amazonian forests. Ecology, vol. 87, no. 7, (suppl.), pp. 150-162. http://dx.doi.org/10.1890/00129658(2006)87[150:TGTAHS]2.0.CO;2. PMid:16922310.

FROSI, M., ZAGO, A.M., BOHNERT, C., SANTOS, I.D., ROMERO, L.V., RIGÃO, C.S. and BOTTARI, N.B., 2012. Determinação da capacidade antioxidante das folhas da Murta. In: Proceedings of the XXII Simpósio de Plantas Medicinais do Brasil, 18-21 September 2012, Bento Gonçalves, Brazil. Rio Grande do Sul: Universidade Federal do Rio Grande do Sul, 1 p.

FUÃO, A.P.G., 2014. Efeitos do extrato aquoso da murta (Blepharocalyx salicifolius) e possiveis mecanismos de ação envolvidos sobre parâmetros hemodinâmicos de ratos. Uruguaiana: Universidade Federal do Pampa, 53 p. Master's dissertation in Biochemistry.

GEORGE, S., BRAT, P., ALTER, P. and AMIOT, M.J., 2005. Rapid Determination of Polyphenols and Vitamin C in PlantDerived Products. Journal of Agricultural and Food Chemistry, vol. 53, no. 5, pp. 1370-1373. http://dx.doi.org/10.1021/jf048396b. PMid: 15740008 .

GOBBO-NETO, L. and LOPES, N.P., 2007. Plantas medicinais: fatores de influência no conteúdo de metabólitos secundários. Quimica Nova, vol. 30, no. 2, pp. 374-381. http://dx.doi.org/10.1590/ S0100-40422007000200026. 
GODINHO, W.M., FARNEZI, M.M., PEREIRA, I.M., GREGÓRIO, L.E. and GRAEL, F.F., 2014. Volatile constituents from leaves of Blepharocalyx salicifolius (Kunth) O. Berg (Mrtaceae). Boletín Latinoamericano y del Caribe de Plantas Medicinales y Aromáticas, vol. 13, no. 3, pp. 249-253.

HABERMANN, E., IMATOMI, M., PEREIRA, V.C., PONTES, F.C. and GUALTIERI, S.C.J., 2015a. Atividade fitotóxica de cascas do caule e folhas de Blepharocalyx salicifolius Kuth O. Berg (Myrtaceae) sobre espécies infestantes. Acta Biologica Colombiana, vol. 20, no. 1, pp. 153-162. http://dx.doi.org/10.15446/ abc.v20n1.42756.

HABERMANN, E., PEREIRA, V.C., IMATOMI, M., PONTES, F.C. and GUALTIERI, S.C.J., 2015b. Fitotoxicidade e fracionamento biodirigido dos extratos de cascas de Blepharocalyx salicifolius (Kunth) O. Berg (Myrtaceae). Biotemas, vol. 28, no. 1, pp. 37-44. http://dx.doi.org/10.5007/33217.

HAKIME-SILVA, R.A., VELLOSA, J.C.R., KHALIL, N.M., KHALIL, O.A.K., BRUNETTI, I.L. and OLIVEIRA, O.M.M.F., 2013. Chemical, enzymatic and cellular antioxidant activity studies of Agaricus blazei Murill. Anais da Academia Brasileira de Ciencias, vol. 85, no. 3, pp. 1073-1082. http://dx.doi.org/10.1590/ S0001-37652013005000044. PMid:23969852.

HALLIWELL, B., AESCHBACH, R., LOLIGER, J. and ARUOMA, O.I., 1995. The characterization of antioxidants. Food and Chemical Toxicology, vol. 33, no. 7, pp. 601-617. http://dx.doi. org/10.1016/0278-6915(95)00024-V. PMid:7628797.

HARTMANN, T., 1996. Global harmonization of herbal health claims. Entomologia Experimentalis et Applicata, vol. 80, no. 1, pp. 177-179. http://dx.doi.org/10.1111/j.1570-7458.1996.tb00914.x.

KÖEPPEN, W., 1948. Climatologia com um estúdio de los climas de la tierra. Ciudad de Mexico: Fondo de Cultura Economica. 479 p.

KRINGS, U. and BERGER, R.G., 2001. Antioxidant activity of some roasted foods. Journal Food Chemistry, vol. 72, no. 2, pp. 223-229. http://dx.doi.org/10.1016/S0308-8146(00)00226-0.

LIZCANO, L.J., BAKKALI, F., BEGOÑA RUIZ-LARREA, M. and IGNACIO RUIZ-SANZ, J., 2010. Antioxidant activity and polyphenol content of aqueous extracts from Colombian Amazonian plants with medicinal use. Food Chemistry, vol. 119, no. 4, pp. 1566-1570. http://dx.doi.org/10.1016/j.foodchem.2009.09.043.

LUO, H., YAMAMOTO, Y., KIM, J.A., JUNG, J.S., KOH, Y.J. and HUR, J.S., 2009. Lecanoric acid, a secondary lichen substance with antioxidant properties from Umbilicaria antarcticain maritime Antarctica (King George Island). Polar Biology, vol. 32, no. 4, pp. 1033-1040. http://dx.doi.org/10.1007/s00300-009-0602-9.

MANACH, C., WILLIAMSON, G., MORAND, C., SCALBERT, A. and RÉMÉSY, C., 2005. Bioavailability and bioefficacy of polyphenols in humans. I. Review of 97 bioavailability studies. The American Journal of Clinical Nutrition, vol. 81, no. 1, (suppl.), pp. 230-242. PMid:15640486.

OTSUKA, H., 2005. Purification by solvent extraction using partition coefficient. In: S.D. SARKER, Z. LATIF and A.I. GRAY. Natural products isolation: methods in biotechnology. New York: Humana Press, pp. 269-273.

OZCELIK, O., LEE, J.H. and MIN, D.B., 2003. Effects of light, oxygen and $\mathrm{pH}$ on the Absorbance of 2,2-diphenyl-1-picrylhydrazyl. Journal of Food Science, vol. 68, no. 2, pp. 487-490. http://dx.doi. org/10.1111/j.1365-2621.2003.tb05699.x.
PIRIZ, M.A., MESQUITA, M.K., CAVADA, C.T., PALMA, J.S., CEOLIN, T. and HECK, R.M., 2013. Uso de plantas medicinais: impactos e perspectivas no cuidado de enfermagem em uma comunidade rural. Revista eletrônica de Enfermagem, vol. 15, no. 4 , pp. $992-999$

RAHMAN, I. and ADCOCK, I.M., 2006. Oxidative stress and redox regulation of lung inflammation in COPD. The European Respiratory Journal, vol. 28, no. 1, pp. 219-242. http://dx.doi.or g/10.1183/09031936.06.00053805. PMid:16816350.

REGO, S.S., NOGUEIRA, A.C., KUNIYOSHI, Y.S. and SANTOS, A.F.D., 2010. Caracterização morfológica do fruto, da semente e do desenvolvimento da plântula de Blepharocalyx salicifolius (H.B.K.) Berg. e Myrceugenia gertii Landrum - Myrtaceae. Revista Brasileira de Sementes, vol. 32, no. 3, pp. 52-60. http:// dx.doi.org/10.1590/S0101-31222010000300006.

REPETTO, M.G. and LLESUY, S.F., 2002. Antioxidant properties of natural compounds used in popular medicine for gastric ulcers. Brazilian Journal of Medical and Biological Research, vol. 35, no. 5, pp. 523-534. http://dx.doi.org/10.1590/S0100879X2002000500003. PMid:12011936.

ROMERO, L.V., BOHNERT, C., SANTOS, I.D., RIGÃO, C.S., ZAGO, A.M., FROSI, M. and PIGATTO, A.G.S., 2012. Análise fitoquímica da murta: resultados preliminaries. In: Proceedings of the XVI Simpósio de Ensino, Pesquisa e Extensão (SEPE): aprender e empreender na educação e na ciência, 3-5 October 2012, Santa Maria-RS. Santa Maria: UNIFRA, pp. 1-2.

Rostagno, M., PAlma, M. and BARroso, C., 2003. Ultrasound-assisted extraction of soy isoflavones. Journal of Chromatography. A, vol. 1012, no. 2, pp. 119-128. http://dx.doi. org/10.1016/S0021-9673(03)01184-1. PMid:14521308.

RUFINO, N.S.M., 2008. Propriedades funcionais de frutas tropicais brasileiras não tradicionais. Mossoró: Universidade Federal Rural do Semi-Árido, 237 p. PhD Thesis in Fitotecnia.

SCHERER, R. and GODOY, H.T., 2009. Antioxidant activity index (AAI) by the 2,2-diphenyl-1-picrylhydrazyl method. Food Chemistry, vol. 112, no. 2, pp. 654-658. http://dx.doi.org/10.1016/j. foodchem.2008.06.026.

SHAHIDI, F., 1997. Natural antioxidants: an overview. In: F. SHAHIDI. Natural antioxidants chemistry, health effects, and applications. Urbana: AOCS Press, pp. 1-11.

SINGLETON, V.L. and ROSSI, J.A., 1965. Colorimetry of total phenolics with phosphomolybdic-phosphotungstic acid reagents. American Journal of Enology and Viticulture, vol. 16, no. 3 , pp. $144-158$.

SIQUEIRA, E.P., OLIVEIRA, D.M., JOHANN, S., CISALPINO, P.S., COTA, B.B., RABELLO, A., ALVES, T.N.A. and ZANI, C.L., 2011. Bioactivity of the compounds isolated from Blepharocalyx salicifolius. Revista Brasileira de Farmacognosia, vol. 21, no. 4, pp. 645-651. http://dx.doi.org/10.1590/S0102-695X2011005000111.

SUYENAGA, E.S., SANTOS, L.R., MARTINS, L.S. and BUENO, F., 2007. O risco de plantas medicinais indicadas por ervateiros no tratamento da sinusite em Porto Alegre. Estudos, vol. 34, no. 6, pp. 833-842.

TAIZ, L. and ZEIGER, E., 2013. Fisiologia vegetal. Porto Alegre: Artmed. 918 p. 
VELLOSA, J.C.R., BARBOSA, V.F. and OLIVEIRA, O.M.M.F., 2007. Pesquisa de Produtos Naturais: Plantas e Radicais Livres. Revista Eletrônica de Farmácia, vol. 4, no. 2, pp. 119-130.

VINSON, J.A., ZUBIK, L., BOSE, P., SAMMAN, N. and PROCH, J., 2005. Dried Fruits: excellent in vitro and in vivo antioxidants. Journal of the American College of Nutrition, vol. 24, no. 1, pp. 44-50. http://dx.doi.org/10.1080/07315724.2005. 10719442. PMid:15670984.

VIVOT, E.P., SÁNCHEZ, C., CACIK, F. and SEQUIN, C., 2012. Actividad antibacteriana em plantas medicinales de la flora de
Entre Ríos (Argentina). Ciencia, Docencia y Technologia, vol. 23 , no. 45 , pp. $165-185$.

YILDIRIM, A., MAVI, A. and KARA, A.A., 2001. Determination of antioxidant and antimicrobial activities of Rumex crispus L. extracts. Journal of Agricultural and Food Chemistry, vol. 49, no. 8, pp. 4083-4089. http://dx.doi.org/10.1021/jf0103572. PMid:11513714.

ZARENA, A.S. and SANKAR, K.U., 2009. A study of antioxidant properties from Garcinia mangostana L. pericarp extract. Acta Scientiarum Polonorum. Technologia Alimentaria, vol. 8, no. 1, pp. 23-34. 